\title{
Human Umbilical Cord Blood Stem Cells Rescue Ischemic Tissues
}

\author{
Dong-Hyuk Park ${ }^{1}$, Jeong-Hyun Lee ${ }^{2}$, David J. Eve ${ }^{3}$, Cesario V. Borlongan ${ }^{3}$, \\ Paul R. Sanberg, 3 , Yong-Gu Chung1 and Tai-Hyoung Cho ${ }^{1}$ \\ ${ }^{1}$ Department of Neurosurgery, Korea University Medical Center, \\ Korea University College of Medicine, Seoul, \\ ${ }^{2}$ Department of Anesthesiology and Pain Medicine, Samsung Medical Center, \\ Sungkyunkwan University School of Medicine, Seoul, \\ ${ }^{3}$ Center of Excellence for Aging and Brain Repair, Department of Neurosurgery and Brain \\ Repair, University of South Florida College of Medicine, Tampa, \\ ${ }^{4}$ Office of Research and Innovation, University of South Florida, Tampa, \\ 1,2 Korea \\ $3,4 U S A$
}

\section{Introduction}

Stroke causes irreversible and permanent damage in the brain immediately adjacent to the region of reduced blood perfusion. The only Food and Drug Administration (FDA)approved drug treatment for acute ischemic stroke is the thrombolytic, tissue-plasminogen activator (t-PA), which acts by dissolving the blood clot in the vessel, and restoring proper blood flow, but is only effective if administered within 3 hours of onset. However, only a few stroke patients are seen within 3 hours of the initial onset of an ischemic stroke and thus have the opportunity at full restoration of blood flow with rapid management by t-PA therapy. Meanwhile, the irreversible loss of myocytes after myocardial infarction (MI) also caused by impaired blood flow, followed by fibrosis of the myocardial scar, infarct expansion, concentric hypertrophy, and left ventricular dilation ultimately leads to progressive heart failure. Current clinical interventions to minimize the devastating effects of myocardial infarction are frequently not sufficient to prevent left ventricular remodeling and subsequent development of heart failure, emphasizing the need for more effective therapies.

These two disorders are related by common features as they are both prevalent in the elderly worldwide. The obstruction of blood vessels reduces the availability of blood to the tissues, causes the specific tissue-related symptoms, and eventually damages or destroys the tissues. Despite interventional and medical advances, the number of people suffering from these disorders is on the rise. Most importantly, there are currently no effective treatments for these ischemic disorders after permanent tissue injury.

Human umbilical cord blood (HUCB) has been used to treat children with various hematological malignant and nonmalignant diseases (Sirchia and Rebulla, 1999). More than six thousand HUCB transplantations have been performed worldwide (Laughlin et al., 2001; 
Tse and Laughlin, 2005; Wagner et al., 1992), since HUCB was first used to successfully treat a 5-year-old child suffering from Fanconi anemia in 1988 (Gluckman et al., 1989). Recently, a number of reports reveal the many advantages of HUCB cells for cellular therapies, especially compared to bone marrow (BM) stem cells. HUCB cells are immature and elicit a lower incidence of graft rejection, graft versus host disease (GvHD), and post-transplant infections even though they primarily come from an allogeneic origin (Knutsen and Wall, 1999; Tse and Laughlin, 2005). The immaturity of cord blood stem cells has been implicated in the optimal effects of these cells for hematopoietic and somatic organ therapy. Over the past years, many researchers have investigated the therapeutic potential of progenitor cells found within HUCB for stroke and MI. We have demonstrated that systemic administration of HUCB cells provides significant benefits in the stroke and MI animal models. Interestingly, rather than the conventional cell replacement mechanism, we advance alternative pathways of graft-mediated brain repair involving trophic effects resulting from release of various growth factors that afford cell survival, angiogenesis, and antiinflammation. Here is a critical literature review of the therapeutic benefits of HUCB stem cell transplantation for stroke and MI in pre-clinical experiments.

\section{The nature of human umbilical cord blood cells}

Hematopoietic progenitors in HUCB are the most primitive and are able to repopulate blood lineages for a long time (Broxmeyer et al., 1992; Nayar et al., 2002; Todaro et al., 2000). The number of myeloid progenitors in HUCB is similar to the number found in BM (Broxmeyer et al., 1992), however, HUCB cells have a greater colony-forming ability (Nakahata and Ogawa, 1982). Thus, they can be expanded in long-term cultures in vitro using different growth factors and have longer telomeres than other adult stem cells (Vaziri et al., 1994). Furthermore, it has been shown that HUCB grafts, compared to adult BM stem cells, are more efficient at restoring the host's hematopoietic progenitor cell reservoir (Frassoni et al., 2003).

The mononuclear fraction of HUCB, is primarily composed of lymphocytes and monocytes (Pranke et al., 2001). It has a comparable B-cell population and a lower absolute number of cluster of differentiation 3 positive $\left(\mathrm{CD}^{+}\right) \mathrm{T}$-cells but a higher $\mathrm{CD} 4^{+} / \mathrm{CD}^{+}$ratio compared to adult peripheral blood (Harris et al., 1992; Pranke et al., 2001). When comparing the characteristics of B-cell differentiation in vitro from CD34+ ${ }^{+}$cord blood cells with those of peripheral blood, B-cell precursors that are differentiated from cord blood, appear to be more immature (Hirose et al., 2001). The relative immunological immaturity of HUCB, compared to adult cell sources, is further classified by a higher proportion of immature Tcells and decreased numbers of mature memory T-cells (Harris et al., 1992). Moreover, cord blood lymphocytes express cytokine receptor profiles such as interleukin (IL)-2, IL-6, IL-7, tumor necrosis factor (TNF)- $\alpha$, and interferon (IFN)- $\gamma$ at lower levels compared to adult blood cells (Zola et al., 1995) and produce greater amounts of the anti-inflammatory cytokines such as IL-10 (Gluckman and Rocha, 2005, Rainsford and Reen, 2002). IL-10 downregulates expression of CD86 on dendritic cells (DCs), which may prevent initiation of the Tcell mediated inflammatory reaction (Buelens et al., 1995). Increased levels of IL-10 may stimulate regulatory T-cells, which in turn inhibit antigen-specific immune responses (Asseman and Powrie, 1998). HUCB also contains more natural killer (NK) cells but lower numbers of $\mathrm{CD}^{+} 6^{+}$cytotoxic T-cells (D'Arena et al., 1998). NK cells can inhibit T-cell proliferation and reduce TNF- a production (El Marsafy et al., 2001). The DCs, which are the 
sentinel cells of the body and initiate immune responses within the lymph nodes, in cord blood reflect lymphoid DCs that are most likely to be responsible for colonizing neonatal tissue, while they are more myeloid in adults (Willing et al., 2007). The lymphoid DCs induce T-helper cell 2 (anti-inflammatory) responses, which along with the naïve T-cells, may promote down-regulation of immune responses (Arpinati et al., 2000; Willing et al., 2007). The immaturity of the immunological properties of HUCB cells probably causes a prolonged immunodeficient status after HUCB transplantation (Garderet et al., 1998; Thomson et al., 2000). This may explain the low incidence of GvHD and viral transmission. Such a cellular constitution could also allow for less strict donor-recipient matching requirements, hence leading to a shorter waiting period for treatment (Newcomb et al., 2007). Rocha et al. found that GvHD incidence was significantly lower in children receiving HUCB transplants compared to BM recipients when the source was from an human leukocyte antigen (HLA)-identical sibling (Rocha et al., 2000).

The level of maturity of a cell is identified by the cell's combination of surface antigens. For example, the $\mathrm{CD} 34^{+}$population, a marker designated for its role in early hematopoiesis, in HUCB can be defined as more primitive than those found in BM because a higher proportion of them are negative for CD38, a marker for pre-lymphoid cells (Cardoso et al., 1993; Conrad and Emerson, 1998). Not only does the mononuclear fraction contain roughly $1 \% \mathrm{CD} 4^{+}$cells but these cells appeared to be more immature than those found in BM (Newcomb et al., 2007). Another human antigen, CD133, has also been identified as a hematopoietic stem cell marker that may provide an alternative to CD34 for the selection and expansion of hematopoietic cells for transplantation (Kobari et al., 2001; Yin et al., 1997). It has been shown that about $80 \%$ of $\mathrm{CD}_{34}{ }^{+}$cells express CD133 and more than $97 \%$ of CD $133^{+}$cells are $\mathrm{CD} 133^{+} \mathrm{CD} 34^{+}$in fresh cord blood (Hao et al., 2003). Although CD133+ cells comprised $0.67 \%$ of the total mononuclear HUCB cells (Ma et al., 2002), expansion of CD $133^{+}$and $\mathrm{CD} 133^{+} \mathrm{CD} 34^{+}$cells was significantly higher than those from the CD $34^{+}$cells (Hao et al., 2003). These findings suggest that $\mathrm{CD} 133^{+}$cells may be more primitive hematopoietic progenitor/stem cells than CD $34^{+}$cells. Furthermore, $\mathrm{CD} 133^{+}$cells have been identified in fetal brain and in this area they are considered to be neural stem cells (NSCs) (Tamaki et al., 2002; Uchida et al., 2000). Meanwhile, we identified in vitro two different subpopulations of mononuclear HUCB cells- adherent and floating (N. Chen et al., 2005). Whereas the adherent cell population mainly contained lymphocytes expressing hematopoietic antigens, there are a significant number of stem cell and neural cell antigens expressed on cells in the floating population. These results suggest that a nonhematopoietic subpopulation of cells exists within the mononuclear fraction of HUCB cells and they seem to have the potential to become neural-like cells. Thus, HUCB seems to include a primitive stem cell population that may give rise to both hematopoietic and neural cells (Garbuzova-Davis et al., 2006). A recent study suggests that the $\mathrm{CD} 133^{+}$population of cells within cord blood can be induced to differentiate along specific lineages, but cell-cell contact is required (Park et al., 2009). However, as described below, other studies suggest that culture in the presence of specific factors is normally sufficient.

A nonhematopoietic stem cell, the mesenchymal stem cell (MSC), has also been found in UCB (Goodwin et al., 2001; Yang et al., 2004). It has been confirmed that MSCs and MSC-like progenitors can be isolated from amniotic fluid, placenta, and HUCB. Moreover, MSCs derived from HUCB show impressive plasticity and differentiate into cells of all three germline derivatives (Jeong et al., 2004; Lee et al., 2004; Yang et al., 2004). However, determining 
a definitive phenotype as well as the surface antigens of MSCs from HUCB has proven to be controversial, unlike that from BM. HUCB MSCs failed to produce macrophage, granulocyte-erythroid-macrophage-megakaryocyte, or granulocyte-macrophage hematopoietic colonies in methylcellulose, whereas supernatants from cultured HUCB MSCs promoted survival of NT2N neural cells and peripheral blood mononuclear cells when cultured under conditions designed to induce cell stress and limit protein synthesis (El-Badri et al., 2006). Furthermore, after incubation in neural differentiation medium, HUCB MSCs expressed the neural cell surface antigen A2B5, the neurofilament polypeptide NF 200, the oligodendrocyte precursor marker 04, intermediate filament proteins characteristic of neural differentiation (nestin and vimentin), as well as the astrocyte marker glial fibrillary acidic protein (GFAP) and the neural progenitor marker class III $\beta$-tubulin (ElBadri et al., 2006). We also demonstrated the immunomodulatory effects of HUCB MSCs after co-culture with murine splenocytes (El-Badri et al., 2006). These results indicate that HUCB MSCs possess multiple utilities that may contribute to their therapeutic potency in the treatment of neurological diseases.

\section{HUCB in preclinical stroke research}

The therapeutic window of current stroke treatment is narrow and restrictive. Many patients seen outside of this window suffer from irreversible deficits. This reality should be taken into consideration when developing other therapeutic options, especially cell-based therapies. HUCB is one of the most promising sources of multipotent stem cells that have shown affirmative effects in in vivo studies for the treatment of stroke. We reviewed the literature focusing on delivery techniques such as the route of administration, time, and dose of HUCB cells given and underlying mechanisms responsible for beneficial effects from the transplantation of HUCB cells.

\subsection{Delivery routes, time, and dose of HUCB stem cells}

Chen et al. showed that the intravenous administration of mononuclear HUCB cells at 24 hours or 7 days after middle cerebral artery occlusion (MCAO) in a rat model of stroke significantly improved neurological function (Chen et al., 2001). Upon histological examination of the brains, mononuclear HUCB cells were observed mainly in the cortex and striatum of the injured hemisphere in the ischemic boundary zone. Few cells were found in the contralateral hemisphere. It was determined that some of these mononuclear HUCB cells were immunoreactive for the endothelial cell marker blood clotting factor VIII (FVIII), GFAP, microtubule-associated protein 2 (MAP2), and neuronal nuclei (NeuN) by immunohistochemistry. Xiao et al. produced a line of cells isolated from HUCB that they called 'nonhematopoietic umbilical cord blood stem cells' by culturing of the mononuclear fraction and cell sorting for specific CD antigens (Xiao et al., 2005). A reduction in infarction volume was observed after intravenous transplantation of these cells into rats with ischemic brain injury. Histological analysis revealed that some of the transplanted cells were double labeled for human nuclei and NeuN, even though it was unlikely that they contributed to the recovery.

Meanwhile, we compared the effect of intravenous versus intrastriatal injection of mononuclear HUCB cells to assess which route produced the greatest behavioral recovery in rats with a permanent MCAO (Willing et al., 2003a). Behavioral improvement was similar 
for both cell delivery routes. Spontaneous activity was significantly less when cells were transplanted 24 hours after stroke compared with non-treated animals. However, 2 months after transplantation, significant improvements were found in the step test only after intravenous delivery of the mononuclear HUCB cells. Also, in the passive avoidance test, transplanted animals learned the task faster than non-transplanted rats. These results suggest that intravenous delivery of mononuclear HUCB cells may be more effective than direct striatal delivery in producing long-term functional benefits to the stroke animal. Next, we investigated the dose effect of mononuclear HUCB cells after MCAO (Vendrame et al., 2004). Twenty-four hours after MCAO, rats were intravenously infused with from $10^{4}$ up to 3-5 × $10^{7}$ mononuclear HUCB cells. At 4 weeks after infusion, there was a significant recovery in behavioral function, when $10^{6}$ or more mononuclear HUCB cells were delivered. Infarct volume analysis showed an inverse relationship between cell dose and damage volume, which reached significance at the higher doses of mononuclear HUCB cells. Moreover, transplanted cells were observed by immunofluorescence for human nuclei antigen expression, to be localized only in the injured brain hemisphere and spleen. Taken together, this suggests that there may be a dose relationship between introduced transplanted cells, behavioral improvement, and neuronal sparing using mononuclear HUCB cell infusion in the MCAO rat stroke model.

For translation from research to clinical application, it will be important to determine how soon after onset, HUCB cells should be transplanted for the best treatment of stroke. Our group determined the optimal time to administer these cells after a stroke. Using ischemic tissue extracts in an in vitro assay, we investigated the migration capability of mononuclear HUCB cells (Newman et al., 2005). This assay revealed increased migration of mononuclear HUCB cells towards both the hippocampal and striatal extracts that were harvested 24-72 hours after stroke. Cytokine-induced neutrophil chemoattractant-1 (CINC-1) and monocyte chemotactic protein-1 (MCP-1) were increased in the extracts at 48 hours after MCAO. This suggests that these substances probably participate in the cell migration. Further analysis showed that growth-regulated oncogene/CINC-1 (the rat equivalent of human IL-8) and MCP-1 were expressed in a time-dependent pattern similar to that of the migration assays. The chemokines which are present in the supernatant may play a major role in the specific mechanisms responsible for the in vivo migration of mononuclear HUCB cells after stroke induction (Newman et al., 2005). Recently, we demonstrated that, in vivo, the HUCB treatment window is not particularly wide. When we intravenously injected the HUCB cells at times ranging from 3 hours to 30 days after MCAO, maximal improvements were observed with treatment at 48 hours (Newcomb et al., 2006). According to a recent study by Riegelsberger et al., neither the infarct volume nor cleaved caspase 3 activity was significantly affected by intravenous HUCB cell transplantation 24 hours after stroke onset (Riegelsberger et al., 2011). In addition, a recent study of MCAO in spontaneously hypertensive rats demonstrated a therapeutic window of upto 72 hours with intravenous injection of $1 \times 10^{6} \mathrm{HUCB}$ mononuclear cells based on lesion size and behavioral impairment (Boltze et al., 2011a). The different rat species may explain the slightly longer therapeutic window compared with our studies. These results are promising in that by using mononuclear HUCB cell therapy, the current 3 hour time window of t-PA for the treatment of stroke may be extended to at least 24 hours after the stroke event. These findings suggest that relatively delayed systemic transplantation of HUCB cells failed to produce neuroprotective effects in a permanent stroke rat model. Taken together these results 
suggest that the grafts actually exist over a very short time frame to either appropriately control the immune system or provide secretory products to cells within the brain to confer therapeutic effects.

\subsection{Probable mechanisms responsible for neural protection}

Although several reports revealed that HUCB cells expressed neural phenotypes both in vitro and in vivo (Garbuzova-Davis et al., 2003; Ha et al., 2001; Sanchez-Ramos et al., 2001; Zigova et al., 2002), few cord blood cells survive in the ischemic region compared to the number of infused cells (Chen et al., 2006; Vendrame et al., 2004, 2005; Willing et al., 2003a, $2003 \mathrm{~b}$ ). In addition, two studies using mannitol to permeate the blood brain barrier showed that the passage of growth factors into the brain following MCAO and neonatal hypoxic ischemia was more important than cell migration from the circulation following intravenous injection (Borlongan et al., 2004; Yasuhara et al., 2010). These findings suggest that cell replacement is not the primary mechanism responsible for the functional improvements seen in these animal studies. Recent research in our team has found that HUCB may not only act as a cell replacement source, but also as a neurotrophic, neuroprotective and antiinflammatory agent. We found that there was an increase in the number of CD45 $5^{+} \mathrm{CD} 11 \mathrm{~b}^{+}$ and $\mathrm{CD} 45^{+} / \mathrm{B} 220^{+} \mathrm{B}$-cells in the brain of rats with permanent MCAO, while the number of $\mathrm{CD}_{4} 5^{+} / \mathrm{CD}_{11 b^{+}}$and $\mathrm{CD} 45^{+} / \mathrm{B} 220^{+}$B-cells in the brain significantly decreased after mononuclear HUCB cell transplantation (Vendrame et al., 2005). The reduction of $\mathrm{CD}_{4} 5^{+} / \mathrm{CD} 11 \mathrm{~b}^{+}$cells is of particular interest, given that chronic microgliosis is believed to mediate neuronal damage, not only in ischemic injury but also in other neurodegenerative diseases (Streit et al., 1999; Tan et al., 1999). HUCB treatment also decreases the proinflammatory cytokines such as TNF- $\alpha$ and IL-1 $\beta$, in the brain following stroke as well as reducing the presence of both activated microglia and astrocytes (Vendrame et al., 2005). Therefore, the potential anti-inflammatory effects of HUCB therapy may protect against neuronal death while evidence suggests that the $\mathrm{CD} 34^{+}$component of the transplant may facilitate revascularization (Taguchi et al., 2004). These cellular changes were accompanied by decreases in mRNA and protein expression of pro-inflammatory cytokines in the brain of stroke animals treated with mononuclear HUCB cells. In our next studies, we revealed that, following $\mathrm{MCAO}$, rat spleen size was decreased concomitantly with their CD8 ${ }^{+} \mathrm{T}$-cell counts (Vendrame et al., 2006). Interestingly, the MCAO-induced reduction in spleen size correlated with the extent of ischemic damage, however, HUCB cell treatment prevented the reduction in spleen weight and splenic $\mathrm{CD}^{+} \mathrm{T}$-cell counts, as well as reducing the degree of brain injury. Additionally, splenocyte proliferation assays demonstrated that HUCB cell treatment opposed MCAO associated T-cell proliferation by increasing the production of IL10 while decreasing IFN- $\gamma$.

As mentioned above, the HUCB cell preparation is a mixed population composed of immature T-cells, B-cells, monocytes/macrophages, and stem cells. Thus, it is important to determine whether the beneficial effects of HUCB injection can be attributed to a specific cell population. Recently, we found that the whole mononuclear fraction of cord blood, stem cell-, T-cell-, and B-cell-depleted preparations improved the function of the impaired left forelimb to a similar extent that exceeded the performance of MCAO-only animals (Womble et al., 2009). However, animals that received the monocyte/macrophage-depleted HUCB preparation performed more poorly than those receiving the other HUCB cells. Additionally, HUCB administration significantly reduced MCAO-induced hyperactivity, 
while depletion of stem cells, monocytes $\left(\mathrm{CD} 14^{+}\right)$, and B cells prevented this recovery following stroke. These results suggest that stem cells, monocytes $\left(\mathrm{CD} 14^{+}\right)$, and B cells are critical to HUCB-induced recovery following stroke. A study performed in Germany confirmed that the mixed mononuclear cell population was most effective at neuroprotection against ischemia caused by MCAO in a spontaneously hypertensive rats (Boltze et al., 2011b). They showed that CD34+ cells contributed to this effect in vitro against oxygen-glucose deprivation (OGD), but did not appear to be important in vivo, since a CD34- cell population from HUCB was equally effective.

The expression of cytokines and chemokines produced by HUCB cells under various culturing conditions was also investigated (Newman et al., 2006). The heterogeneous cells from mononuclear fractions of HUCB produced a variety of cytokines when grown in various culture conditions. In particular, IL-8, MCP-1, and IL-1 $\beta$ that have been implicated as the first line of defense in the inflammatory reaction, are more extensively produced than other chemokines in the human body, especially the brain. These results suggest that these factors may be partially responsible for the functional improvements that were observed in the animal stroke models investigating the therapeutic use of HUCB cells. On the other hand, we recently showed that chemokines are also elevated in the ischemic brain area in an in vivo study (Jiang et al., 2008). MCP-1 and macrophage inflammatory protein (MIP)-1a seem to play a role in the infiltration of monocytes into the central nervous system under pathological conditions (Babcock et al., 2003; Glabinski et al., 1998). We found that MCP-1 and MIP-1a expression were significantly increased in the ischemic brain, and significantly promoted HUCB cell migration compared to the contralateral side (Jiang et al., 2008). This cell migration was neutralized with polyclonal antibodies against MCP-1 and MIP-1a. Chemokine receptors were also expressed on the surface of transplanted HUCB cells. These findings suggest that the increased chemokines within the ischemic lesion can bind surface receptors on the HUCB cells, and induce homing of systemically delivered HUCB cells into the CNS in vivo. Recently, Ou et al. showed the potential of intravenous transplantation of HUCB CD34+ cells transfected with the glial cell line-derived neurotrophic factor (GDNF) gene to exert therapeutic benefits in spontaneous hypertensive rats exposed to a transient MCAO (Ou et al., 2010). The stroke animals transplanted with GDNF-modified CD34+ cells showed a significant increase in GDNF protein levels in the infarcted hemisphere, reduced brain infarction volume, and enhanced functional recovery compared to those that received CD34+ cells only.

The immune system and inflammation are known to play a role in the development of stroke. Possible mechanisms of action for HUCB cells include the modification of this effect. Using an organotypic slice culture and OGD, a recent study showed that an intact immune system is not required for the beneficial effects of HUCB cells (Hall et al., 2009a). Cell survival was increased and the release of nitric oxide by resident microglia (an innate inflammatory response) was reduced back to normal levels following incubation with the cells. Further study showed that the secretion of IL-1 $\beta$ by microglia was impaired following hypoxia in the presence of HUCB cells and microglia viability was also decreased (Jiang et al., 2010). In vivo, HUCB cells were shown to impair the recruitment of pro-inflammatory microglia and hence the secretion of matrix metalloproteinase 9 and nitric oxide at the site of injury following MCAO (Leonardo et al., 2010). The microglia found at the site of injury tended to be of a ramified shape, which is believed to be a quiescent inactive form.

Protein and microarray analysis of neuronal co-cultures with HUCB cells following OGD revealed the upregulation of a number of specific genes which coincided with improved 
survival (Shahaduzzaman et al., 2010). Several of these genes e.g. peroxiredoxin were verified as being upregulated in vivo also, demonstrating that transplantation of HUCB cells promotes survival gene expression within the brain. OGD treatment of PC12 cells followed by co-culture with HUCB also demonstrated increased cell survival which was shown to be related to the appearance of antioxidants as well as neurotrophic and angiogenic factors (Arien-Zakay et al, 2009).

The majority of studies on stroke and potential therapies focus on the neurons. However, ischemia also affects the white matter and therefore therapies should focus on both the neurons and the oligodendrocytes that myelinate the axons found in the white matter. Two recent studies by the Willing and Pennypacker group demonstrate that infusion of HUCB cells 48 hours after MCAO was also able to protect oligodendrocytes by reducing caspase 3 activation (Hall et al., 2009b) and promoting the expression of genes associated with oligodendrocyte survival, proliferation and function (Rowe et al., 2010). A further study using HUCB-derived MSCs transduced to express hepatocyte growth factor revealed increased behavioral recovery and enhanced remyelination in an intracranial hemorrhage model compared to untransduced MSCs (Liu et al., 2010). In the latter study, the cells were transplanted one week after hemorrhage directly into the left ventricle. These studies demonstrate an additional means by which HUCBs could promote recovery from a stroke by aiding survival of oligodendrocyte survival and myelination of axons.

While the majority of studies suggest mechanisms other than cell replacement, a recent study in canines demonstrated survival of intra-arterially injected HUCB-derived MSCs in a thromboembolic brain ischemia model at 4 weeks (Chung et al., 2009). The cells were injected one day after lesion and were shown to decrease the lesion volume and differentiate into neurons and astrocytes in the neighborhood of von Willebrand factor-positive endothelial cells suggesting an association with new blood vessels.

\section{HUCB in preclinical myocardial infarction research}

As shown in stroke investigations, the mechanisms by which HUCB stem cells protect cardiomyocytes and improve cardiac function seem to be complex and multifactorial. Transplanted HUCB cells can differentiate into cardiomyocyte-like cells (Cheng et al., 2003; Wu et al., 2006), induce neovascularization in the necrotic area (Botta et al., 2004; Ma et al., 2005; Wu et al., 2007a), modulate the inflammatory reaction induced by ischemic cascades (Henning et al., 2006), and secrete growth factors including vascular endothelial growth factor (VEGF) (Hu et al., 2006; Tang et al., 2005). However, there are some in vitro studies that suggest that HUCB stem cells in culture do not differentiate into cardiomyocytes. Roura et al. used a number of different methods including culture of HUCB cells with 5azacytidine, early cardiomyogenesis growth factor cocktails, Wnt signaling activators or direct neonatal rat cardiomyocyte contact and did not observe any transdifferentiation (Roura et al., 2010). By comparison, Avitabile et al. recently reported that CD $34^{+}$HUCB cells adopted a cardiomyocyte-like phenotype following co-culture with mouse neonatal cardiomyocytes not due to transdifferentiation, but instead by cell fusion with the neonatal cardiomyocytes (Avitabile et al, 2011). These studies would seem to suggest that the in vivo influences which appear to cause transdifferentiation (Cheng et al., 2003; Wu et al., 2006), may not be adequately modeled in vitro.

The optimal timing and dose of HUCB stem cell administration for treating MI are also critical issues as shown in the animal stroke studies. In most of the previous investigations, 
HUCB stem cells that were administered within 24 hours after MI exerted benefits on cardiac function (Botta et al., 2004; H. K. Chen et al., 2005; Henning et al., 2004; Hirata et al., 2005). By contrast, a wide range of HUCB cell numbers were examined in the MI animal models and functional benefits seem to be partly dose-dependent (Botta et al., 2004; H. K. Chen et al., 2005; Henning et al., 2004; Hirata et al., 2005; Kim et al., 2005; Ma et al., 2005). Meanwhile, as with stroke treatments, a variety of administration routes for HUCB cells, including intramyocardial injection, intracoronary injection and intravenous routes, were demonstrated as effective and safe. Henning et al. looked at a variety of doses and a variety of routes within 2 hours of ligation of the left coronary artery (Henning et al., 2007). They found that intramyocardial, intra-arterial and intravenous injection of cells, all produced similar significant reductions in infarct size when examined 1 month later, but with different optimum doses of cells $\left(4 \times 10^{6}, 4 \times 10^{6}\right.$ and $16 \times 10^{6}$ respectively) and concluded that intramyocardial injection appeared to be best. Below we review further reports focusing on the delivery routes of HUCB stem cells to treat MI in animal models.

\subsection{Intramyocardial injection}

Direct transplantation of HUCB stem cells into the myocardium of the infarcted heart has been widely investigated in in vivo studies due to the advantage that it provides a direct route to the damaged area. Hirata et al. showed the therapeutic effects of HUCB CD34 ${ }^{+}$cells on MI in rats (Hirata et al., 2005). CD34+ cell transplantation significantly improved ventricular function as revealed by echocardiography and hemodynamic analysis. Immunohistochemistry studies for human CD34, CD45, and CD31 (Platelet endothelial cell adhesion molecule; PECAM-1) revealed that transplanted HUCB cells survived in the host rat myocardium. These findings suggest that transplanted HUCB cells survived, enhanced neovascularization and improved cardiac function after $\mathrm{MI}$ in the animal models. Interestingly, Higuchi et al. recently showed, using iron oxide and sodium iodide symporter reporter gene transfected $\mathrm{CD} 34^{+} \mathrm{HUCB}$ cells, that transplanted cells did not survive for more than 7 days when $4 \times 10^{6}$ cells were injected directly into normal rat hearts (Higuchi et al, 2009). This suggests that the damaging effects of a myocardial infarction may promote the survival of transplanted cells. Botta et al. transplanted different subpopulations of HUCB cells into the peri-ischemic area at 24 hours after left anterior descending coronary artery (LAD) ligation in the non-obese diabetic-severe combined immune deficient (NOD-SCID) mouse model (Botta et al., 2004). They showed that $\mathrm{CD}^{+} 4^{+} \mathrm{KDR}^{+}$(kinase insert domain receptor) cells or $\mathrm{CD}_{3} 4^{+}$cells significantly improved the rate of rise of left ventricular pressure $(\mathrm{dP} / \mathrm{dt})$ and left ventricle $(\mathrm{LV})$ end diastolic pressure in cardiac function after MI, whereas the same number of $\mathrm{CD} 34^{+} \mathrm{KDR}$ - cells did not have any benefit. In histological studies, a limited number of human nuclear antigen positive cells were observed within the cardiomyocytes of mice receiving $\mathrm{CD}^{2} 4^{+} \mathrm{KDR}^{+} \mathrm{HUCB}$ cells. These results suggest that $\mathrm{CD}^{+} 4^{+} \mathrm{KDR}^{+}$cells are probably an active subpopulation within $\mathrm{CD}^{2} 4^{+}$cells. Their remarkable resistance to apoptosis and angiogenic ability may contribute to their beneficial effects on the damaged cardiac tissues.

Meanwhile, Henning et al. injected $1 \times 10^{6}$ HUCB mononuclear cells into the infarcted myocardium 1 hour after rats underwent LAD ligation (Henning et al., 2004). Compared to the vehicle group, the ejection fraction of the HUCB cell-treated group was not decreased significantly at 1 month, but progressively increased at 3 and 4 months. At 4 months, in the HUCB cell-treated group, anteroseptal wall thickening and increased $\mathrm{dp} / \mathrm{dt}$ (max) were 
markedly greater than in the vehicle group. Infarct sizes in the HUCB cell treated group were smaller than the vehicle group at 3 and 4 months. These findings suggest that HUCB cell transplantation substantially reduces infarct size associated with improvement of left ventricular function in the rat MI model. Of interest, Kim et al. reported that HUCB cells improved cardiac function even when transplanted 4 weeks after ischemia (Kim et al., 2005). In this study, the distal LAD of Yorkshire pigs was occluded by endovascular coil embolization. Human unrestricted somatic stem cells (USSCs) isolated from HUCB following culturing of the mononuclear fraction under specific conditions (Kogler et al., 2004) or culture media were directly injected into the infarcted area at 4 weeks after ischemia. At 4 weeks after transplantation, single-photon emission computed tomography technetium $99 \mathrm{~m}$ sestamibi radioisotope scans revealed improved regional perfusion and wall motion of the infarct region in the cell-treated group compared to the non-treated control group. Ejection fraction decreased in the control group while it increased in the transplant group. The grafted cells were detected 4 weeks after transplantation by both immunohistochemistry and in situ hybridization, and they improved regional and global function after MI. Transplanting $1 \times 10^{5}$ or $1 \times 10^{6}$ USSCs intramyocardially, 20 minutes after ligation in a rat model, was recently shown to lead to a dose-dependent generation of human cardiomyocytes and vasculogenesis which could be detected 4 weeks later. This was determined by the colocalization of cardiac troponin-I and human nuclear antigen as well as class I HLA staining and smooth muscle actin and von Willebrand factor and human nuclear antigen respectively (Iwasaki et al, 2009). These findings suggest that USSCs from HUCB also can be a good candidate for cell-based therapies to treat MI and suggest that they may function to promote new blood vessel growth and cell replacement. Wu et al. also reported a significant improvement of cardiac function in rats with MI that were treated with HUCB-derived stem cells compared to the control untreated group (Wu et al., 2007b). Four weeks after transplantation, histological studies revealed that some of the grafted HUCB-derived stem cells survived in the host infarcted myocardium and accumulated around arterioles and scattered in capillary networks. Some of the cells expressed cardiac troponin-T, von Willebrand factor, and smooth muscle actin, suggesting that transplanted HUCB-derived stem cells in the infarcted myocardium can differentiate into cardiomyocytic, endothelial, and smooth muscle cells to repair damaged myocardium. The capillary and arteriole density were also significantly elevated in the HUCB cell-treated group, while the number of apoptotic cells decreased significantly. Taken together, cardiogenesis and angiogenesis probably exert a favorable influence on the recovery of cardiac function even after chronic administration of HUCB cells in the animals with acute MI. Hu et al. also demonstrated that angiogenesis induced by transplanted cells plays a major role in cardiac remodeling and improvement of cardiac function in animal MI models (Hu et al., 2006). HUCB mononuclear cells were transplanted into the marginal area of the infarcted myocardium immediately after LAD ligation. One month after MI, the grafted cells survived in the host heart and the collagen density in the LV was significantly lower in the transplanted group, which coincided with higher mRNA expression of VEGF. These results suggest that angiogenesis promoted by transplanted HUCB mononuclear cells in the infarcted area play a critical role in cardiac repair in the MI animal models. Recently, Hu et al. investigated the therapeutic efficacy and feasibility of intramyocardial transplantation of $1 \times 10^{6}$ human umbilical cord blood-derived endothelial progenitor cells (hUCB-EPCs) in 
rats with acute MI (Hu et al., 2009, 2010). These cells were obtained by culturing adherent cells from the mononuclear fraction under specific media conditions. The cell therapy group had increased microvessel formation and a decreased degree of myocardial fibrosis compared to the control non-treated group. The increased microvessel formation was shown to come from both upregulation of endogenous rat cells (as shown by increased rat proliferating cell nuclear antigen and rat PECAM expression) and colocalization of human nuclear antigen and CD31 and anti-VIII staining. Moreover, the degree of myocardial fibrosis was less than that of the control group. The improved global heart function and decreased cardiac fibrosis in rats with acute MI implies the potential benefit of hUCB-EPC transplantation.

Meanwhile, Henning et al. revealed that the transplantation of HUCB cells attenuated the inflammatory and immune reaction induced by ischemic cascades (Henning et al., 2006), which likely contributed to the cardiac regeneration of the infarcted heart. Implantation of HUCB cells into infarcted myocardium of non-immunosuppressed rats within 2 or at 24 hours after LAD occlusion, limited the expression of pro-inflammatory cytokines such as TNF- $\alpha$, MCP-1, MIP-1 $\alpha$, and IFN- $\gamma$ in the infarcted myocardium and it may be associated with significant decreases in infarct volume. Further analysis was carried out by transplanting $4 \times 10^{6}$ cells and performing cytokine analysis and inflammatory cell recruitment at 2, 6, 12, 24 and 72 hours after LAD ligation (Henning et al., 2008). They observed that the infiltration of inflammatory cells and secretion of inflammatory cytokines was significantly reduced by HUCB cells within 2 hours compared to non-treatment after LAD occlusion and this was maintained through to 72 hours.

The number of cells required to be effective in clinical applications, is likely to mean that the cells would need to be expanded in vitro prior to delivery. Senegaglia et al. investigated whether in vitro expansion of $\mathrm{CD}_{133^{+}}$endothelial progenitor cells derived from HUCB affected their ability to improve the left ventricular ejection fraction following $\mathrm{MI}$ in a rat model (Senegaglia et al., 2010). 200,000 expanded or purified (non-expanded) cells were transplanted intramyocardially 7 days after infarction and the left ventricular ejection fraction was found to be equally improved. This suggested that in vitro expansion did not alter the transplanted cell's function suggesting that it may be safe to expand these cells in vitro. Further studies would be necessary to see if any benefit is conferred by expansion (apart from the more readily available supply of cells) since the authors did report that the expanded cells expressed VEGF mRNA whereas non-expanded did not in vitro. However the expansion methods are currently not sufficiently reliable to be used routinely (see later). Of interest, Ma et al. compared the effects of cell transplantation between BM stem cells and HUCB stem cells for injured myocardium. HUCB CD133+ cells $\left(5 \times 10^{5}\right)$ were injected directly into the infarcted myocardium induced by cryoinjury of NOD/SCID mice (Ma et al., 2006a; 2006b). An equivalent number of CD133+ BM cells were transplanted and a sham injection was performed in the respective control groups. Both BM CD133+ and HUCB $\mathrm{CD}_{133^{+}}$cells increased capillary density in the injured myocardium, whereas only BM $\mathrm{CD}_{133^{+}}$cells improved myocardial contractility assessed by echocardiography in vivo. Armiñán et al. also suggest that mesenchymal stem cells derived from bone marrow maybe more effective than $\mathrm{CD} 34^{+}$cells isolated from UCB following intramyocardial injection into a nude rat model of MI 7 days after infarction (Armiñán et al., 2010). Both cell types led to improved cardiac function, cardiac cell proliferation and neoangiogenesis, but the MSCs appeared to be more effective at reducing infarct size. However, it is important to note that 
in their study Armiñán et al. used twice as many MSCs than CD34+ cells $\left(1.2 \times 10^{6}\right.$ vs. $\left.6 \times 10^{5}\right)$ making it difficult to really make a comparison. Gaebel et al. demonstrated that MSCs derived from 3 different sources - human BM, HUCB and human adipose tissue - were differentially able to heal male SCID mice after LAD ligation (Gaebel et al, 2011). 400,000 cells were transplanted immediately after ligation and the hearts examined 6 weeks later. While each cell type had some benefit, the best results were seen with the BM-derived cells. However, they also showed that HUCB-derived MSCs had a lower proportion of CD105+ (endoglin, a type 1 membrane glycoprotein) cells compared to the other sources, which decreased further with additional passaging. A purified preparation of CD105 ${ }^{+} \mathrm{HUCB}$ cells was shown to possess a similar benefit as BM-derived MSCs. Endoglin is known to be involved in the development of the cardiovascular system and vascular remodeling, which may explain its apparent importance in transplanted cells (Gaebel et al, 2011).

Using a right ventricle overload model, autologous sheep UCB mononuclear cells were shown to improve the diastolic properties of the right ventricle (Yerebakan et al., 2009). The authors suggested that this occurred due to increased angiogenesis. This is one of the few examples of autologous UCB cell transplantation for myocardial impairments so far reported.

\subsection{Systemic injection}

A number of studies explored the usefulness and effectiveness of the systemic route including intravenous and intra-arterial administration, which could have clinical potential because the procedure is minimally invasive and a minimal burden to the recipients suffering from critical diseases, even though it raises the doubt of adequate homing to the lesion. However, as shown in animal stroke or MI models, there has been emerging evidence suggesting that a significant proportion of the HUCB cells which are systemically administered, will migrate into the infarcted brain or heart lesion and the animals show improvement in their behavioral deficits.

Ma et al. revealed the homing ability of HUCB mononuclear cells that were injected in the tail vein of NOD/SCID mice that had (MI+) or had not (MI-) received ligation of the LAD (Ma et al., 2005). Human DNA (hDNA) was detected in marrow, spleen, and liver of both MI+ and MI- mice from 24 hours to 3 weeks after cell injection. By contrast, hDNA was found in the hearts of $53 \%$ of MI+ mice but in none of the MI- mice. Infarct size was smaller and collagen deposition was reduced in the cell-treated group. Capillary density in the border zone of the MI was approximately $20 \%$ higher, and clusters of HUCB-derived cells were detected in the perivascular interstitium in cell-treated MI+ mice, though the vast majority of new vessels seemed to originate from the endogenous mouse cells. There was no evidence of cardiomyocyte differentiation of the intravenously grafted HUCB mononuclear cells. Interestingly, in infarcted myocardium, stromal cell-derived factor (SDF)-1 mRNA was expressed approximately 7-fold higher than in normal hearts. These results suggest that systemically administered HUCB cells can migrate into the faraway infarcted lesion where they play a role in neovascularization, and beneficially influence tissue-remodeling processes. Leor et al. administered HUCB-derived $\mathrm{CD} 133^{+}$progenitor cells intravenously at 7 days after permanent coronary artery ligation in athymic nude rats (Leor et al., 2006). One month after transplantation, LV fractional shortening was much improved. Moreover, anterior wall thickness decreased significantly in control group but not in HUCB cell-treated group. The grafted HUCB cells were found to have migrated and survived in the infarcted myocardium on microscopic examination. Human originated-cells were detected near vessel 
walls and LV cavity in the HUCB cell-treated rats. They were incorporated into endothelial cells in six out of the nine cell-treated animals. Scar tissue from cell-treated animals was significantly populated with autologous myofibroblasts as indicated by colocalization of HLA-DR and alpha-smooth muscle actin staining. These findings suggest that intravenous transplanted HUCB cells can migrate, survive, and be incorporated into the host myocardium and produce functional recovery in animal MI models.

A couple of studies focused on the mechanisms of how the systemically transplanted HUCB cells are recruited into the site of tissue damage. Henning et al. revealed that the greatest HUCB cell migration into the infarcted myocardium persisted at 2 and 24 hours after LAD occlusion (Henning et al., 2006). Increased SDF-1 in the infarcted myocardium attracts circulating stem cells through the CXCR4 receptor, leading to activation of surface integrins and subsequent recruitment into the vasculature (Ma et al., 2005). These findings suggest that the recruitment of transplanted cells to the injured site was likely due to the concentrations of chemoattractants within the ischemic and infarcted tissues.

Another study using an unspecified number of cells attempted to explore the optimal time for transplantation via the caudal vein (Xing et al., 2009). They injected HUCB cells 1, 5, 10 or 30 days after LAD ligation and they measured cardiac function 4 weeks later. Animals transplanted 5 and 10 days after LAD ligation showed improved cardiac function, with the best results occurring in the 10 day transplant animals. The best survival, more pronounced angiogenesis and VEGF expression was observed within these animals, though no evidence of cardiac regeneration was seen. The authors proposed that the angiogenic effects were the main cause of the improvement. It is worth noting that the authors characterized the cells prior to transplantation and showed that only $35-42 \%$ of the cells were CD34 ${ }^{+}$.

Lineage-depleted HUCB cells that express high levels of the cytosolic enzyme aldehyde dehydrogenase (ALDH) were found to possess a high long term repopulation potential whereas cells with low levels of ALDH had negligible long term repopulation potential (Sondergaard et al., 2010). Intravenous administration of these cells one day after LAD ligation in NOD/SCID mice showed specific localization to the injured area within 48 hours and engraftment was higher 4 weeks later using the high ALDH expressing population compared to the low expressing population (Sondergaard et al., 2010). However none of the transplanted cells were observed to became cardiomyocytes, but a few became endothelial cells and the surviving cells were associated with increased vascular density. It is worth noting that only a small number of cells were transplanted ( 400,000 cells), which may not be sufficient to see the best effects when administered systemically. These studies show that there are a number of cell types in HUCB which differ in their CD markers and enzyme levels which could affect their ability to be effective.

\subsection{Intracoronary delivery}

Intracoronary injection can be classified as via the systemic route as it is a subtype of intraarterial infusion. This method is somewhat more complicated than peripheral access, but can easily be accomplished within several minutes in a well-equipped coronary suite with well-trained physicians. Thus, this method is directly applicable to the real clinical situation. Moreover, intracoronary delivery has an advantage over the intravenous route since the stem cells can be delivered directly to the infarcted myocardium without passing through the systemic circulation. This aspect alleviates the possibility of systemic cell loss such as cell trapping within the lungs and spleen. However, there is also a disadvantage with intra- 
arterial infusion, since the transplanted cells can form clumps or aggregates if very large quantities of cells are infused, which can subsequently become an embolus (Qian et al., 2006).

While a number of studies have examined the feasibility and efficacy of intracoronary infusion of BM stem cells or peripheral blood-derived mononuclear cells for treating $\mathrm{MI}$ in animal and human models (Bartunek et al., 2005; Manginas et al., 2007; Qian et al., 2006), there are few published studies using HUCB cells. Moelker et al. failed to show improvement of LV function by intracoronary administration of HUCB cells after MI (Moelker et al., 2007). In this study, approximately $10^{8} \mathrm{HUCB}$ stem cells were injected via the intracoronary route 1 week after MI and reperfusion in a swine model. By this time point, end-diastolic volume and LV mass were larger, while ejection fraction was smaller. Regional wall thickening in the left circumflex coronary artery area became akinetic. There was no difference in global and regional LV function at 5 weeks between MI animals receiving HUCB stem cells or normal medium, while surprisingly the infarct size after HUCB stem cell treatment was significantly larger. Transplanted HUCB cells survived only in the infarct border zone at 5 weeks and did not express cardiomyocyte or endothelial markers. Of interest, histological examination revealed that HUCB stem cells transplanted through intracoronary infusion caused micro-infarctions by obstructing vessels. Although the feasibility and efficacy of intracoronary delivery of HUCB could not be determined because there has been few studies about this issue, these results raise safety concerns due to embolic infarction related with the high dose of transplanted HUCB cells required for the intracoronary route (Moelker et al., 2007; Qian et al., 2006).

\subsection{Tissue engineering and gene modification}

Recent investigations focusing on gene therapy or tissue engineering demonstrate that the combination of stem cell and gene modification may be a useful treatment modality for MI treatment (Mangi et al., 2003; Matsumoto et al., 2005). However, gene manipulation of stem cells outside the body and in the laboratory before transplantation raises safety problems as well as possible moral and ethical concerns when it is applied clinically.

Cortes-Morichetti et al. examined the feasibility of a collagen matrix seeded with HUCB stem cells and their engraftment onto infarcted ventricles (Cortes-Morichetti et al., 2007). Echocardiography and histological examination implied that the cell-loaded matrix and the cell implants appeared to be an effective alternative to prevent post-MI ventricular dilation and cardiac remodeling compared to either HUCB cells or collagen matrix alone-treated groups. These results suggest that stem cell implantation accompanied with tissue engineering techniques, probably augment the efficacy of simple cellular therapy and could emerge as a new therapeutic modality to prevent adverse remodeling and progressive heart failure.

Meanwhile, Chen et al. studied the efficacy of HUCB cells with genes inserted to overexpress angiogenic factors that were subsequently transplanted into infarcted ventricles $(\mathrm{H}$. K. Chen et al., 2005). In this study, HUCB CD34+ cells were transfected with adeno-associated virus (AAV) vectors encoding either human angiopoietin (Ang1; AAV-Ang1) or VEGF (AAVVEGF) cDNA alone, or both combined (AAV-Ang1 plus VEGF). After LAD ligation in SCID mice, they administered the expanded CD34+ cells transduced with AAV-Ang1, AAV-VEGF or AAV-Ang1 plus VEGF intramyocardially at the left anterior wall. Western blot analysis revealed that Ang1 and VEGF expressions were increased in the CD34+ cells transduced 
with AAV-Ang1 and AAV-VEGF, respectively. Infarct size significantly decreased and capillary density remarkably increased after treatment with CD34+/AAV-Ang1 plus VEGF compared to the treatment with $\mathrm{CD} 34^{+}$cells only. Combination therapy with $\mathrm{CD} 34^{+} / \mathrm{AAV}-$ Ang1, CD34 ${ }^{+}$AAV-VEGF, and CD34 ${ }^{+} / \mathrm{AAV}-$ Ang1 plus VEGF, all expressed remarkably higher cardiac performance in echocardiography than the CD34+ cells alone 4 weeks after MI. These results suggest that combination therapy with HUCB CD34 ${ }^{+}$cells and overexpression of both Ang1 and VEGF genes decreases infarct size, improves cardiac dysfunction and elevates capillary density in acute $\mathrm{MI}$ in mice to a greater extent compared to HUCB hematopoietic stem cell only transplantation.

Pretreatment of HUCB cells with oxytocin prior to transplant has been shown to promote their activity. Oxytocin stimulates cell proliferation and may promote cardiomyogenesis (Kim et al., 2010). Kim et al. transplanted $10^{6}$ pretreated cells intramyocardially after LAD ligation and found that cardiac fibrosis and macrophage $\left(\mathrm{CD} 68^{+}\right)$infiltration was reduced by oxytocin pretreatment. Engraftment, connexion 43 expression and cardiac contractility were increased, but angiogenesis did not appear to be altered in animals administered pretreated cells (Kim et al., 2010). This suggests that oxytocin pretreatment may increase the proliferation and differentiation of the transplanted cells, but does not appear to influence blood vessel growth.

\section{Conclusions}

Ischemic insults to neural tissue and the myocardium involve complicated inflammatory cascades that eventually lead to a pronounced cell death adjacent to the obstructed vasculature. The appropriate delivery of HUCB cells most likely prevents the apoptotic cascade, regenerates damaged cells and tissues, and modulates the inflammatory response to ischemic injury. Another advantage in using HUCB cells for the treatment of ischemic damage is the potential restoration of vascularity since cord blood contains endothelial progenitor cells and hematopoietic stem cells which may be of use in neovascularization therapy.

However, there are still a number of obstacles that prevent the routine application of HUCB cell transplantation to treat human stroke or MI patients as follows. First, safety has not been effectively determined in terms of immunological rejection when allogeneic transplantation is considered. HUCB cells are likely to be used primarily for transplantation into allogeneic recipients, though as HUCB cell banking becomes more popular autologous transplants may become more common in the future. Although HUCB cells are less immunogenic, long term studies should be considered to evaluate the long term safety with or without immunosuppression. Jozwiak et al. and Yang et al. have reported on using HUCB cells for the safe treatment of a single case of global brain ischemia and in a number of neurological disorders (including stroke) respectively with short term follow-up (Jozwiak et al., 2010; Yang et al., 2010). Second, because HUCB collection can only be performed at single timepoints (i.e. during birth), and the number of stem cells extracted from one donor is very limited, expansion of the stem cells is mandatory. Unfortunately, current methods of expanding HUCB cells do not preserve the quality of the hematopoietic progenitor cells through to the end product (Jaroscak et al., 2003; Robinson et al., 2005). Current expansion methods cannot make up for the cells lost in the storage process, let alone augment them to a suitable dosing regimen (Hows et al., 1992; Liu et al., 2006; Traycoff et al., 1995; Yao et al., 2006). However, in the last couple of years, there have been several studies looking at ways 
to maximize yield, storage and recovery, and expansion which require validation (Gonzalez et al., 2010; Koestenbauer et al., 2009; Lin et al., 2010; Song et al., 2010; Vanneaux et al., 2010; Zeisburger et al., 2010). Third, the cause of limited graft survival in the recipient remains to be determined even though the paradigm of underlying mechanisms on the functional improvement after stem cell transplantation has been changed from cell replacement to a paracrine bystander effect. The longer the grafts survive, probably the better the neurological or cardiac function recovers. When these hurdles are overcome in the not too distant future, HUCB cell therapy may become a promising treatment modality for ischemic diseases including stroke and MI with multiple therapeutic potentials and a longer effective time frame in a single transplant that no other currently available pharmacological agent could mimic.

\section{Acknowledgements}

This work was supported in part by a Korea University Grant (K1030571) and Basic Science Research Program through the National Research Foundation of Korea (NRF) funded by the Ministry of Education, Science and Technology (2011-0013525). PRS is a co-founder and CVB a consultant for Saneron CCEL Therapeutics, Inc, a company exploring the therapeutic applications of stem cells including HUCB. CVB and PRS hold patents on the use of HUCB for the treatment of neurodegenerative disorders.

\section{References}

Arien-Zakay, H., Lecht, S., Bercu, M. M., Tabakman, R., Kohen, R., Galski, H., Nagler, A. \& Lazarovici, P. (2009). Neuroprotection by cord blood neural progenitors involves antioxidants, neurotrophic and angiogenic factors. Exp Neurol 216, 83-94.

Armiñán, A., Gandía, C., García-Verdugo, J. M., Lledó, E., Trigueros, C., Ruiz-Saurí, A., Miñana, M. D., Solves, P., Payá, R., Montero, J. A. \& Sepúlveda, P. (2010). Mesenchymal stem cells provide better results than hematopoietic precursors for the treatment of myocardial infarction. J Am Coll Cardiol 55, 2244-2253.

Arpinati, M., Green, C. L., Heimfeld, S., Heuser, J. E. \& Anasetti, C. (2000). Granulocytecolony stimulating factor mobilizes T helper 2-inducing dendritic cells. Blood 95, 2484-2490.

Asseman, C. \& Powrie, F. (1998). Interleukin 10 is a growth factor for a population of regulatory T cells. Gut 42, 157-158.

Avitabile, D., Crespi, A., Brioschi, C., Parente, V., Toietta, G., Devanna, P., Baruscotti, M., Truffa, S., Scavone, A., Rusconi, F., Biondi, A., D'Alessandra, Y., Vigna, E., Difrancesco, D., Pesce, M., Capogrossi, M. C. \& Barbuti, A. (2011). Human cord blood CD34+ progenitor cells acquire functional cardiac properties through a cell fusion process. Am J Physiol Heart Circ Physiol 300, H1875-1884.

Babcock, A. A., Kuziel, W. A., Rivest, S. \& Owens, T. (2003). Chemokine expression by glial cells directs leukocytes to sites of axonal injury in the CNS. J Neurosci 23, 7922-7930.

Bartunek, J., Vanderheyden, M., Vandekerckhove, B., Mansour, S., De Bruyne, B., De Bondt, P., Van Haute, I., Lootens, N., Heyndrickx, G. \& Wijns, W. (2005). Intracoronary injection of CD133-positive enriched bone marrow progenitor cells promotes cardiac recovery after recent myocardial infarction: feasibility and safety. Circulation 112, I178-183. 
Boltze, J., Schmidt, U. R., Reich, D. M., Kranz, A., Reymann, K. G., Strassburger, M., Lobsien, D., Wagner, D-C., Förschler, A. \& Schäbitz, W-R. (2011a). Determination of the therapeutic time window for human umbilical cord blood mononuclear cell transplantation following experimental stroke in rats. Cell Transplant Epub ahead of print. DOI: $10.3727 / 096368911 X 589609$.

Boltze, J., Reich, D. M., Hau, S., Reymann, K. G., Strassburger, M., Lobsien, D., Wagner, DC., Kamprad, M. \& Stahl, T. (2011b). Assessment of neuroprotective effects of human umbilical cord blood mononuclear cell subpopulations in vitro and in vivo. Cell Transplant Epub ahead of print. DOI: 10.3727/096368911X586783.

Borlongan, C. V., Hadman, M., Sanberg, C. D. \& Sanberg, P. R. (2004). Central nervous system entry of peripherally injected umbilical cord blood cells is not required for neuroprotection in stroke. Stroke 35, 2385-2389.

Botta, R., Gao, E., Stassi, G., Bonci, D., Pelosi, E., Zwas, D., Patti, M., Colonna, L., Baiocchi, M., Coppola, S., Ma, X., Condorelli, G. \& Peschle, C. (2004). Heart infarct in NODSCID mice: therapeutic vasculogenesis by transplantation of human CD34+ cells and low dose CD34+KDR+ cells. FASEB J 18, 1392-1394.

Broxmeyer, H. E., Hangoc, G., Cooper, S., Ribeiro, R. C., Graves, V., Yoder, M., Wagner, J., Vadhan-Raj, S., Benninger, L., Rubinstein, P. \& Broun, E. R. (1992). Growth characteristics and expansion of human umbilical cord blood and estimation of its potential for transplantation in adults. Proc Natl Acad Sci U S A 89, 4109-4113.

Buelens, C., Willems, F., Delvaux, A., Pierard, G., Delville, J. P., Velu, T. \& Goldman, M. (1995). Interleukin-10 differentially regulates B7-1 (CD80) and B7-2 (CD86) expression on human peripheral blood dendritic cells. Eur J Immunol 25, 2668-2672.

Cardoso, A. A., Li, M. L., Batard, P., Hatzfeld, A., Brown, E. L., Levesque, J. P., Sookdeo, H., Panterne, B., Sansilvestri, P., Clark, S. C. \& Hatzfeld, J. (1993). Release from quiescence of CD34+ CD38- human umbilical cord blood cells reveals their potentiality to engraft adults. Proc Natl Acad Sci U S A 90, 8707-8711.

Chen, J., Sanberg, P. R., Li, Y., Wang, L., Lu, M., Willing, A. E., Sanchez-Ramos, J. \& Chopp, M. (2001). Intravenous administration of human umbilical cord blood reduces behavioral deficits after stroke in rats. Stroke 32, 2682-2688.

Chen, H. K., Hung, H. F., Shyu, K. G., Wang, B. W., Sheu, J. R., Liang, Y. J., Chang, C. C. \& Kuan, P. (2005). Combined cord blood stem cells and gene therapy enhances angiogenesis and improves cardiac performance in mouse after acute myocardial infarction. Eur J Clin Invest 35, 677-686.

Chen, N., Hudson, J. E., Walczak, P., Misiuta, I., Garbuzova-Davis, S., Jiang, L., SanchezRamos, J., Sanberg, P. R., Zigova, T. \& Willing, A. E. (2005). Human umbilical cord blood progenitors: the potential of these hematopoietic cells to become neural. Stem Cells 23, 1560-1570.

Chen, S. H., Chang, F. M., Tsai, Y. C., Huang, K. F., Lin, C. L. \& Lin, M. T. (2006). Infusion of human umbilical cord blood cells protect against cerebral ischemia and damage during heatstroke in the rat. Exp Neurol 199, 67-76.

Cheng, F., Wang, H. W., Cuenca, A., Huang, M., Ghansah, T., Brayer, J., Kerr, W. G., Takeda, K., Akira, S., Schoenberger, S. P., Yu, H., Jove, R. \& Sotomayor, E. M. (2003). A critical role for Stat3 signaling in immune tolerance. Immunity 19, 425-436.

Chung, D. J., Choi, C. B., Lee, S. H., Kang, E. H., Lee, J. H., Hwang, S. H., Han, H., Lee, J. H., Choe, B. Y., Lee, S.Y. \& Kim, H. Y. (2009). Intraarterially delivered human umbilical 
cord blood-derived mesenchymal stem cells in canine cerebral ischemia. J Neurosci Res 87, 3554-3567.

Conrad, P. D. \& Emerson, S. G. (1998). Ex vivo expansion of hematopoietic cells from umbilical cord blood for clinical transplantation. J Leukoc Biol 64, 147-155.

Cortes-Morichetti, M., Frati, G., Schussler, O., Duong Van Huyen, J. P., Lauret, E., Genovese, J. A., Carpentier, A. F. \& Chachques, J. C. (2007). Association between a cell-seeded collagen matrix and cellular cardiomyoplasty for myocardial support and regeneration. Tissue Eng 13, 2681-2687.

D'Arena, G., Musto, P., Cascavilla, N., Di Giorgio, G., Fusilli, S., Zendoli, F. \& Carotenuto, M. (1998). Flow cytometric characterization of human umbilical cord blood lymphocytes: immunophenotypic features. Haematologica 83, 197-203.

El-Badri, N. S., Hakki, A., Saporta, S., Liang, X., Madhusodanan, S., Willing, A. E., Sanberg, C. D. \& Sanberg, P. R. (2006). Cord blood mesenchymal stem cells: Potential use in neurological disorders. Stem Cells Dev 15, 497-506.

El Marsafy, S., Dosquet, C., Coudert, M. C., Bensussan, A., Carosella, E. \& Gluckman, E. (2001). Study of cord blood natural killer cell suppressor activity. Eur J Haematol 66, 215-220.

Frassoni, F., Podesta, M., Maccario, R., Giorgiani, G., Rossi, G., Zecca, M., Bacigalupo, A., Piaggio, G. \& Locatelli, F. (2003). Cord blood transplantation provides better reconstitution of hematopoietic reservoir compared with bone marrow transplantation. Blood 102, 1138-1141.

Gaebel, R., Furlani, D., Sorg, H., Polchow, B., Frank, J., Bieback, K., Wang, W., Klopsch, C., Ong, L. L., Li, W., Ma, N. \& Steinhoff, G. (2011). Cell origin of human mesenchymal stem cells determines a different healing performance in cardiac regeneration. PLoS One 6, e15652.

Garbuzova-Davis, S., Willing, A. E., Zigova, T., Saporta, S., Justen, E. B., Lane, J. C., Hudson, J. E., Chen, N., Davis, C. D. \& Sanberg, P. R. (2003). Intravenous administration of human umbilical cord blood cells in a mouse model of amyotrophic lateral sclerosis: distribution, migration, and differentiation. J Hematother Stem Cell Res 12, 255-270.

Garbuzova-Davis, S., Willing, A. E., Saporta, S., Bickford, P. C., Gemma, C., Chen, N., Sanberg, C. D., Klasko, S. K., Borlongan, C. V. \& Sanberg, P. R. (2006). Novel cell therapy approaches for brain repair. Prog Brain Res 157, 207-222.

Garderet, L., Dulphy, N., Douay, C., Chalumeau, N., Schaeffer, V., Zilber, M. T., Lim, A., Even, J., Mooney, N., Gelin, C., Gluckman, E., Charron, D. \& Toubert, A. (1998). The umbilical cord blood alphabeta T-cell repertoire: characteristics of a polyclonal and naive but completely formed repertoire. Blood 91, 340-346.

Glabinski, A. R., Tuohy, V. K., \& Ransohoff, R. M. (1998). Expression of chemokines RANTES, MIP-1alpha and GRO-alpha correlates with inflammation in acute experimental autoimmune encephalomyelitis. Neuroimmunomodulation 5, 166-171.

Gluckman, E., Broxmeyer, H. A., Auerbach, A. D., Friedman, H. S., Douglas, G. W., Devergie, A., Esperou, H., Thierry, D., Socie, G., Lehn, P., Cooper, S., English, D., Kurtzberg, J., Bard, J. \& Boyse, E. A. (1989). Hematopoietic reconstitution in a patient with Fanconi's anemia by means of umbilical-cord blood from an HLAidentical sibling. N Engl J Med 321, 1174-1178. 
Gluckman, E. \& Rocha, V. (2005). History of the clinical use of umbilical cord blood hematopoietic cells. Cytotherapy 7, 219-227.

Gonzalez, R., Griparic, L., Umana, M., Burgee, K., Vargas, V., Nasrallah, R., Silva, F. \& Patel, A. (2010). An efficient approach to isolation and characterization of pre- and postnatal umbilical cord lining stem cells for clinical applications. Cell Transplant 19, 1439-1449.

Goodwin, H. S., Bicknese, A. R., Chien, S. N., Bogucki, B. D., Quinn, C. O. \& Wall, D. A. (2001). Multilineage differentiation activity by cells isolated from umbilical cord blood: expression of bone, fat, and neural markers. Biol Blood Marrow Transplant 7, 581-588.

Ha, Y., Choi, J. U., Yoon, D. H., Yeon, D. S., Lee, J. J., Kim, H. O. \& Cho, Y. E. (2001). Neural phenotype expression of cultured human cord blood cells in vitro. Neuroreport 12, 3523-3527.

Hall, A. A., Leonardo, C. C., Collier, L. A., Rowe, D. D., Willing, A. E. \& Pennypacker, K. R. (2009a). Delayed treatments for stroke influence neuronal death in rat organotypic slice cultures subjected to oxygen glucose deprivation. Neuroscience 164, 470-477.

Hall, A. A., Guyer, A. G., Leonardo, C. C., Ajmo, C. T., Jr., Collier, L. A., Willing, A. E. \& Pennypacker, K. R. (2009b). Human umbilical cord blood cells directly suppress ischemic oligodendrocyte cell death. J Neurosci Res 87, 333-341.

Hao, S. G., Sun, G. L., Wu, W. L. \& Wu, Y. L. (2003). [Studies on the dynamics of biological characteristics of CD133+ cells from human umbilical cord blood during short-term culture]. Zhongguo Shi Yan Xue Ye Xue Za Zhi 11, 569-575.

Harris, D. T., Schumacher, M. J., Locascio, J., Besencon, F. J., Olson, G. B., DeLuca, D., Shenker, L., Bard, J. \& Boyse, E. A. (1992). Phenotypic and functional immaturity of human umbilical cord blood T lymphocytes. Proc Natl Acad Sci U S A 89, 1000610010.

Henning, R. J., Abu-Ali, H., Balis, J. U., Morgan, M. B., Willing, A. E. \& Sanberg, P. R. (2004). Human umbilical cord blood mononuclear cells for the treatment of acute myocardial infarction. Cell Transplant 13, 729-739.

Henning, R. J., Burgos, J. D., Ondrovic, L., Sanberg, P., Balis, J. \& Morgan, M. B. (2006). Human umbilical cord blood progenitor cells are attracted to infarcted myocardium and significantly reduce myocardial infarction size. Cell Transplant 15, 647-658.

Henning, R. J., Burgos, J. D., Vasko, M., Alvarado, F., Sanberg, C. D., Sanberg, P. R. \& Morgan, M. B. (2007). Human cord blood cells and myocardial infarction: effect of dose and route of administration on infarct size. Cell Transplant 16, 907-917.

Henning, R. J., Shariff, M., Eadula, U., Alvarado, F., Vasko, M., Sanberg, P. R., Sanberg, C. D. \& Delostia, V. (2008). Human cord blood mononuclear cells decrease cytokines and inflammatory cells in acute myocardial infarction. Stem Cells Dev 17, 1207-1219.

Higuchi, T., Anton, M., Dumler, K., Seidl, S., Pelisek, J., Saraste, A., Welling, A., Hofmann, F., Oostendorp, R. A., Gansbacher, B., Nekolla, S. G., Bengel, F. M., Botnar, R. M. \& Schwaiger, M. (2009). Combined reporter gene PET and iron oxide MRI for monitoring survival and localization of transplanted cells in the rat heart. $\mathrm{J} \mathrm{Nucl}$ Med 50, 1088-1094 
Hirata, Y., Sata, M., Motomura, N., Takanashi, M., Suematsu, Y., Ono, M. \& Takamoto, S. (2005). Human umbilical cord blood cells improve cardiac function after myocardial infarction. Biochem Biophys Res Commun 327, 609-614.

Hirose, Y., Kiyoi, H., Itoh, K., Kato, K., Saito, H. \& Naoe, T. (2001). B-cell precursors differentiated from cord blood CD34+ cells are more immature than those derived from granulocyte colony-stimulating factor-mobilized peripheral blood CD34+ cells. Immunology 104, 410-417.

Hows, J. M., Bradley, B. A., Marsh, J. C., Luft, T., Coutinho, L., Testa, N. G. \& Dexter, T. M. (1992). Growth of human umbilical-cord blood in longterm haemopoietic cultures. Lancet 340, 73-76.

Hu, C. H., Wu, G. F., Wang, X. Q., Yang, Y. H., Du, Z. M., He, X. H. \& Xiang, P. (2006). Transplanted human umbilical cord blood mononuclear cells improve left ventricular function through angiogenesis in myocardial infarction. Chin Med J (Engl) 119, 1499-1506.

Hu, C. H., Li, Z. M., Du, Z. M., Zhang, A. X., Yang, D. Y. \& Wu, G. F. (2009). Human umbilical cord-derived endothelial progenitor cells promote growth cytokinesmediated neorevascularization in rat myocardial infarction. Chin Med J (Engl) 122, 548-555.

Hu, C. H., Li, Z. M., Du, Z. M., Zhang, A. X., Rana, J. S., Liu, D. H., Yang, D. Y. \& Wu, G. F. (2010). Expanded human cord blood-derived endothelial progenitor cells salvage infarcted myocardium in rats with acute myocardial infarction. Clin Exp Pharmacol Physiol 37, 551-556.

Iwasaki, H., Kawamoto, A., Willwerth, C., Horii, M., Oyamada, A., Akimaru, H., Shibata, T., Hirai, H., Suehiro, S., Wnendt, S., Fodor, W. L. \& Asahara, T. (2009). Therapeutic potential of unrestricted somatic stem cells isolated from placental cord blood for cardiac repair post myocardial infarction. Arterioscler Thromb Vasc Biol 29, 18301835.

Jaroscak, J., Goltry, K., Smith, A., Waters-Pick, B., Martin, P. L., Driscoll, T. A., Howrey, R., Chao, N., Douville, J., Burhop, S., Fu, P. \& Kurtzberg, J. (2003). Augmentation of umbilical cord blood (UCB) transplantation with ex vivo-expanded UCB cells: results of a phase 1 trial using the AastromReplicell System. Blood 101, 5061-5067.

Jeong, J. A., Gang, E. J., Hong, S. H., Hwang, S. H., Kim, S. W., Yang, I. H., Ahn, C., Han, H. \& Kim, H. (2004). Rapid neural differentiation of human cord blood-derived mesenchymal stem cells. Neuroreport 15, 1731-1734.

Jiang, L., Newman, M., Saporta, S., Chen, N., Sanberg, C. D., Sanberg, P. R. \& Willing, A. E. (2008). MIP-1alpha and MCP-1 Induce Migration of Human Umbilical Cord Blood Cells in Models of Stroke. Curr Neurovasc Res 5, 118-124.

Jiang, L., Womble, T., Saporta, S., Chen, N., Sanberg, C. D., Sanberg, P. R. \& Willing, A. E. (2010). Human umbilical cord blood cells decrease microglial survival in vitro. Stem Cells Dev 19, 221-228.

Jozwiak, S., Habich, A., Kotulska, K., Sarnowska, A., Kropiwnicki, T., Janowski, M., Jurkiewicz, E., Lukomska, B., Kmiec, T., Walecki, J., Roszkowski, M., Litwin, M., Oldak, T., Boruczkowski, D. \& Domanska-Janik, K. (2010) Intracerebroventricular Transplantation of Cord Blood-derived Neural Progenitors in a Child with Severe Global Brain Ischemic Injury. Cell Med 1, 71-80. 
Kim, B. O., Tian, H., Prasongsukarn, K., Wu, J., Angoulvant, D., Wnendt, S., Muhs, A., Spitkovsky, D. \& Li, R. K. (2005). Cell transplantation improves ventricular function after a myocardial infarction: a preclinical study of human unrestricted somatic stem cells in a porcine model. Circulation 112, I96-104.

Kim, Y. S., Kwon, J. S., Hong, M. H., Kim, J., Song, C. H., Jeong, M. H., Cho, J. G., Park, J. C., Kang, J. C. \& Ahn, Y. (2010). Promigratory activity of oxytocin on umbilical cord blood-derived mesenchymal stem cells. Artif Organs 34, 453-461.

Knutsen, A. P. \& Wall, D. A. (1999). Kinetics of T-cell development of umbilical cord blood transplantation in severe T-cell immunodeficiency disorders. J Allergy Clin Immunol $103,823-832$.

Kobari, L., Giarratana, M. C., Pflumio, F., Izac, B., Coulombel, L. \& Douay, L. (2001). CD133+ cell selection is an alternative to CD34+ cell selection for ex vivo expansion of hematopoietic stem cells. J Hematother Stem Cell Res 10, 273-281.

Koestenbauer, S., Zisch, A., Dohr, G. \& Zech, N. H. (2009) Protocols for hematopoietic stem cell expansion from umbilical cord blood. Cell Transplant 18, 1059-1068.

Kogler, G., Sensken, S., Airey, J. A., Trapp, T., Muschen, M., Feldhahn, N., Liedtke, S., Sorg, R. V., Fischer, J., Rosenbaum, C., Greschat, S., Knipper, A., Bender, J., Degistirici, O., Gao, J., Caplan, A. I., Colletti, E. J., Almeida-Porada, G., Muller, H. W., Zanjani, E. \& Wernet, P. (2004). A new human somatic stem cell from placental cord blood with intrinsic pluripotent differentiation potential. J Exp Med 200, 123-135.

Laughlin, M. J., Barker, J., Bambach, B., Koc, O. N., Rizzieri, D. A., Wagner, J. E., Gerson, S. L., Lazarus, H. M., Cairo, M., Stevens, C. E., Rubinstein, P. \& Kurtzberg, J. (2001). Hematopoietic engraftment and survival in adult recipients of umbilical-cord blood from unrelated donors. N Engl J Med 344, 1815-1822.

Lee, K. D., Kuo, T. K., Whang-Peng, J., Chung, Y. F., Lin, C. T., Chou, S. H., Chen, J. R., Chen, Y. P. \& Lee, O. K. (2004). In vitro hepatic differentiation of human mesenchymal stem cells. Hepatology 40, 1275-1284.

Leonardo, C. C., Hall, A. A., Collier, L. A., Ajmo, C. T., Jr., Willing, A.E. \& Pennypacker, K.R. (2010). Human umbilical cord blood cell therapy blocks the morphological change and recruitment of CD11b-expressing, isolectin-binding proinflammatory cells after middle cerebral artery occlusion. J Neurosci Res 88, 1213-1222.

Leor, J., Guetta, E., Feinberg, M. S., Galski, H., Bar, I., Holbova, R., Miller, L., Zarin, P., Castel, D., Barbash, I. M. \& Nagler, A. (2006). Human umbilical cord blood-derived CD133+ cells enhance function and repair of the infarcted myocardium. Stem Cells 24, 772-780.

Lin, R. Z., Dreyzin, A., Aamodt, K., Dudley, A. C. \& Melero-Martin, J. M. (2011). Functional endothelial progenitor cells from cryopreserved umbilical cord blood. Cell Transplant 20, 515-522.

Liu, A. M., Lu, G., Tsang, K. S., Li, G., Wu, Y., Huang, Z. S., Ng, H. K., Kung, H. F. \& Poon, W. S. (2010). Umbilical cord-derived mesenchymal stem cells with forced expression of hepatocyte growth factor enhance remyelination and functional recovery in a rat intracerebral hemorrhage model. Neurosurgery 67, 357-365; discussion 365-366.

Liu, Y., Liu, T., Fan, X., Ma, X. \& Cui, Z. (2006). Ex vivo expansion of hematopoietic stem cells derived from umbilical cord blood in rotating wall vessel. J Biotechnol 124, 592601. 
Ma, N., Stamm, C., Kaminski, A., Li, W., Kleine, H. D., Muller-Hilke, B., Zhang, L., Ladilov, Y., Egger, D. \& Steinhoff, G. (2005). Human cord blood cells induce angiogenesis following myocardial infarction in NOD/scid-mice. Cardiovasc Res 66, 45-54.

Ma, N., Ladilov, Y., Kaminski, A., Piechaczek, C., Choi, Y. H., Li, W., Steinhoff, G. \& Stamm, C. (2006a). Umbilical cord blood cell transplantation for myocardial regeneration. Transplant Proc 38, 771-773.

Ma, N., Ladilov, Y., Moebius, J. M., Ong, L., Piechaczek, C., David, A., Kaminski, A., Choi, Y. H., Li, W., Egger, D., Stamm, C. \& Steinhoff, G. (2006b). Intramyocardial delivery of human CD133+ cells in a SCID mouse cryoinjury model: Bone marrow vs. cord blood-derived cells. Cardiovasc Res 71, 158-169.

Ma, Y., Zou, P., Xiao, J. \& Huang, S. (2002). [The expression and functional characteristics of AC133 antigen in cord blood hematopoietic cells]. Zhonghua Nei Ke Za Zhi 41, 798800.

Mangi, A. A., Noiseux, N., Kong, D., He, H., Rezvani, M., Ingwall, J. S. \& Dzau, V. J. (2003). Mesenchymal stem cells modified with Akt prevent remodeling and restore performance of infarcted hearts. Nat Med 9, 1195-1201.

Manginas, A., Goussetis, E., Koutelou, M., Karatasakis, G., Peristeri, I., Theodorakos, A., Leontiadis, E., Plessas, N., Theodosaki, M., Graphakos, S. \& Cokkinos, D. V. (2007). Pilot study to evaluate the safety and feasibility of intracoronary CD133(+) and CD133(-) CD34(+) cell therapy in patients with nonviable anterior myocardial infarction. Catheter Cardiovasc Interv 69, 773-781.

Matsumoto, R., Omura, T., Yoshiyama, M., Hayashi, T., Inamoto, S., Koh, K. R., Ohta, K., Izumi, Y., Nakamura, Y., Akioka, K., Kitaura, Y., Takeuchi, K. \& Yoshikawa, J. (2005). Vascular endothelial growth factor-expressing mesenchymal stem cell transplantation for the treatment of acute myocardial infarction. Arterioscler Thromb Vasc Biol 25, 1168-1173.

Moelker, A. D., Baks, T., Wever, K. M., Spitskovsky, D., Wielopolski, P. A., van Beusekom, H. M., van Geuns, R. J., Wnendt, S., Duncker, D. J. \& van der Giessen, W. J. (2007). Intracoronary delivery of umbilical cord blood derived unrestricted somatic stem cells is not suitable to improve LV function after myocardial infarction in swine. J Mol Cell Cardiol 42, 735-745.

Nakahata, T. \& Ogawa, M. (1982). Hemopoietic colony-forming cells in umbilical cord blood with extensive capability to generate mono- and multipotential hemopoietic progenitors. J Clin Invest 70, 1324-1328.

Nayar, B., Raju, G. M. \& Deka, D. (2002). Hematopoietic stem/progenitor cell harvesting from umbilical cord blood. Int J Gynaecol Obstet 79, 31-32.

Newcomb, J. D., Ajmo, C. T., Jr., Sanberg, C. D., Sanberg, P. R., Pennypacker, K. R. \& Willing, A. E. (2006). Timing of cord blood treatment after experimental stroke determines therapeutic efficacy. Cell Transplant 15, 213-223.

Newcomb, J. D., Sanberg, P. R., Klasko, S. K. \& Willing, A. E. (2007). Umbilical cord blood research: current and future perspectives. Cell Transplant 16, 151-158.

Newman, M. B., Willing, A. E., Manresa, J. J., Davis-Sanberg, C. \& Sanberg, P. R. (2005). Stroke-induced migration of human umbilical cord blood cells: time course and cytokines. Stem Cells Dev 14, 576-586. 
Newman, M. B., Willing, A. E., Manresa, J. J., Sanberg, C. D. \& Sanberg, P. R. (2006). Cytokines produced by cultured human umbilical cord blood (HUCB) cells: implications for brain repair. Exp Neurol 199, 201-208.

Ou, Y., Yu, S., Kaneko, Y., Tajiri, N., Bae, E. C., Chheda, S. H., Stahl, C. E., Yang, T., Fang, L., $\mathrm{Hu}, \mathrm{K}$. , Borlongan, C. V. \& Yu, G. (2010). Intravenous infusion of GDNF genemodified human umbilical cord blood CD34+ cells protects against cerebral ischemic injury in spontaneously hypertensive rats. Brain Res 1366, 217-225.

Park, J., Setter, V., Wixler, V. \& Schneider, H. (2009). Umbilical cord blood stem cells: induction of differentiation into mesenchymal lineages by cell-cell contacts with various mesenchymal cells. Tissue Eng Part A 15, 397-406.

Pranke, P., Failace, R. R., Allebrandt, W. F., Steibel, G., Schmidt, F. \& Nardi, N. B. (2001). Hematologic and immunophenotypic characterization of human umbilical cord blood. Acta Haematol 105, 71-76.

Qian, H., Yang, Y., Huang, J., Dou, K. \& Yang, G. (2006). Cellular cardiomyoplasty by catheter-based infusion of stem cells in clinical settings. Transpl Immunol 16, 135147.

Rainsford, E. \& Reen, D. J. (2002). Interleukin 10, produced in abundance by human newborn $\mathrm{T}$ cells, may be the regulator of increased tolerance associated with cord blood stem cell transplantation. Br J Haematol 116, 702-709.

Riegelsberger, U. M., Deten, A., Posel, C., Zille, M., Kranz, A., Boltze, J., \& Wagner, D. C. (2011). Intravenous human umbilical cord blood transplantation for stroke: impact on infarct volume and caspase-3-dependent cell death in spontaneously hypertensive rats. Exp Neurol 227, 218-223.

Robinson, S., Niu, T., de Lima, M., Ng, J., Yang, H., McMannis, J., Karandish, S., Sadeghi, T., Fu, P., del Angel, M., O'Connor, S., Champlin, R. \& Shpall, E. (2005). Ex vivo expansion of umbilical cord blood. Cytotherapy 7, 243-250.

Rocha, V., Wagner, J. E., Jr., Sobocinski, K. A., Klein, J. P., Zhang, M. J., Horowitz, M. M. \& Gluckman, E. (2000). Graft-versus-host disease in children who have received a cord-blood or bone marrow transplant from an HLA-identical sibling. Eurocord and International Bone Marrow Transplant Registry Working Committee on Alternative Donor and Stem Cell Sources. N Engl J Med 342, 1846-1854.

Roura, S., Farré, J., Hove-Madsen, L., Prat-Vidal, C., Soler-Botija, C., Gálvez-Montón, C., Vilalta, M. \& Bayes-Genis, A. (2010). Exposure to cardiomyogenic stimuli fails to transdifferentiate human umbilical cord blood-derived mesenchymal stem cells. Basic Res Cardiol 105, 419-430.

Rowe, D. D., Leonardo, C. C., Hall, A. A., Shahaduzzaman, M. D., Collier, L. A., Willing, A. E. \& Pennypacker, K. R. (2010). Cord blood administration induces oligodendrocyte survival through alterations in gene expression. Brain Res 1366, 172-188.

Sanchez-Ramos, J. R., Song, S., Kamath, S. G., Zigova, T., Willing, A., Cardozo-Pelaez, F., Stedeford, T., Chopp, M. \& Sanberg, P. R. (2001). Expression of neural markers in human umbilical cord blood. Exp Neurol 171, 109-115.

Senegaglia, A. C., Barboza, L. A., Dallagiovanna, B., Aita, C. A., Hansen, P., Rebelatto, C. L., Aguiar, A. M., Miyague, N. I., Shigunov, P., Barchiki, F., Correa, A., Olandoski, M., Krieger, M. A. \& Brofman, P. R. (2010). Are purified or expanded cord bloodderived CD133+ cells better at improving cardiac function? Exp Biol Med (Maywood) 235, 119-229. 
Shahaduzzaman, M., Golden, J. E., Green, S. M., Rowe, D., Pennypacker, K. R. \& Willing, A. E. (2010). Human umbilical cord blood (HUCB) cells protect neurons by altering the neuronal gene expression profile. Cell Transplantation 19, 361.

Sirchia, G. \& Rebulla, P. (1999). Placental/umbilical cord blood transplantation. Haematologica 84, 738-747.

Sondergaard, C. S., Hess, D. A., Maxwell, D. J., Weinheimer, C., Rosová, I., Creer, M. H., Piwnica-Worms, D., Kovacs, A., Pedersen, L. \& Nolta, J. A. (2010). Human cord blood progenitors with high aldehyde dehydrogenase activity improve vascular density in a model of acute myocardial infarction. J Transl Med. 8, 24.

Song, C. H., Kim, J. J., Kim, J., Kim, S. H. \& Kim, Y. G. (2010). Effects of trophogel for adhesion, proliferation, and differentiation of human umbilical cord bloodmesenchymal stem cells (hUCB-MSC). Cell Transplantation 19, 363.

Streit, W. J., Walter, S. A. \& Pennell, N. A. (1999). Reactive microgliosis. Prog Neurobiol 57, 563-581.

Taguchi, A., Soma, T., Tanaka, H., Kanda, T., Nishimura, H., Yoshikawa, H., Tsukamoto, Y., Iso, H., Fujimori, Y., Stern, D. M., Naritomi, H. \& Matsuyama, T. (2004). Administration of CD34+ cells after stroke enhances neurogenesis via angiogenesis in a mouse model. J Clin Invest 114, 330-338.

Tamaki, S., Eckert, K., He, D., Sutton, R., Doshe, M., Jain, G., Tushinski, R., Reitsma, M., Harris, B., Tsukamoto, A., Gage, F., Weissman, I. \& Uchida, N. (2002). Engraftment of sorted/expanded human central nervous system stem cells from fetal brain. $J$ Neurosci Res 69, 976-986.

Tan, J., Town, T., Paris, D., Mori, T., Suo, Z., Crawford, F., Mattson, M. P., Flavell, R. A. \& Mullan, M. (1999). Microglial activation resulting from CD40-CD40L interaction after beta-amyloid stimulation. Science 286, 2352-2355.

Tang, Y. L., Zhao, Q., Qin, X., Shen, L., Cheng, L., Ge, J. \& Phillips, M. I. (2005). Paracrine action enhances the effects of autologous mesenchymal stem cell transplantation on vascular regeneration in rat model of myocardial infarction. Ann Thorac Surg 80, 229-236; discussion 236-237.

Thomson, B. G., Robertson, K. A., Gowan, D., Heilman, D., Broxmeyer, H. E., Emanuel, D., Kotylo, P., Brahmi, Z. \& Smith, F. O. (2000). Analysis of engraftment, graft-versushost disease, and immune recovery following unrelated donor cord blood transplantation. Blood 96, 2703-2711.

Todaro, A. M., Pafumi, C., Pernicone, G., Munda, S., Pilastro, M. R., Russo, A., Farina, M. \& Messina, A. (2000). Haematopoietic progenitors from umbilical cord blood. Blood Purif 18, 144-147.

Traycoff, C. M., Kosak, S. T., Grigsby, S. \& Srour, E. F. (1995). Evaluation of ex vivo expansion potential of cord blood and bone marrow hematopoietic progenitor cells using cell tracking and limiting dilution analysis. Blood 85, 2059-2068.

Tse, W. \& Laughlin, M. J. (2005). Umbilical cord blood transplantation: a new alternative option. Hematology Am Soc Hematol Educ Program, 377-383.

Uchida, N., Buck, D. W., He, D., Reitsma, M. J., Masek, M., Phan, T. V., Tsukamoto, A. S., Gage, F. H. \& Weissman, I. L. (2000). Direct isolation of human central nervous system stem cells. Proc Natl Acad Sci U S A 97, 14720-14725.

Vanneaux, V., El-Ayoubi, F., Delmau, C., Driancourt, C., Lecourt, S., Grelier, A., Cras, A., Cuccuini, W., Soulier, J., Lataillade, J. J., Lebousse-Kerdiles, M. C., Oury, J. F., 
Sibony, O., Marolleau, J. P., Benbunan, M., Uzan, G. \& Larghero, J. (2010). In vitro and in vivo analysis of endothelial progenitor cells from cryopreserved umbilical cord blood: are we ready for clinical application? Cell Transplant 19, 1143-1155.

Vaziri, H., Dragowska, W., Allsopp, R. C., Thomas, T. E., Harley, C. B. \& Lansdorp, P. M. (1994). Evidence for a mitotic clock in human hematopoietic stem cells: loss of telomeric DNA with age. Proc Natl Acad Sci U S A 91, 9857-9860.

Vendrame, M., Cassady, J., Newcomb, J., Butler, T., Pennypacker, K. R., Zigova, T., Sanberg, C. D., Sanberg, P. R. \& Willing, A. E. (2004). Infusion of human umbilical cord blood cells in a rat model of stroke dose-dependently rescues behavioral deficits and reduces infarct volume. Stroke 35, 2390-2395.

Vendrame, M., Gemma, C., de Mesquita, D., Collier, L., Bickford, P. C., Sanberg, C. D., Sanberg, P. R., Pennypacker, K. R. \& Willing, A. E. (2005). Anti-inflammatory effects of human cord blood cells in a rat model of stroke. Stem Cells Dev 14, 595604.

Vendrame, M., Gemma, C., Pennypacker, K. R., Bickford, P. C., Davis Sanberg, C., Sanberg, P. R. \& Willing, A. E. (2006). Cord blood rescues stroke-induced changes in splenocyte phenotype and function. Exp Neurol 199, 191-200.

Wagner, J. E., Broxmeyer, H. E., Byrd, R. L., Zehnbauer, B., Schmeckpeper, B., Shah, N., Griffin, C., Emanuel, P. D., Zuckerman, K. S., Cooper, S., Carow, C., Bias, W. \& Santos, G. W. (1992). Transplantation of umbilical cord blood after myeloablative therapy: analysis of engraftment. Blood 79, 1874-1881.

Willing, A. E., Lixian, J., Milliken, M., Poulos, S., Zigova, T., Song, S., Hart, C., SanchezRamos, J. \& Sanberg, P. R. (2003a). Intravenous versus intrastriatal cord blood administration in a rodent model of stroke. J Neurosci Res 73, 296-307.

Willing, A. E., Vendrame, M., Mallery, J., Cassady, C. J., Davis, C. D., Sanchez-Ramos, J. \& Sanberg, P. R. (2003b). Mobilized peripheral blood cells administered intravenously produce functional recovery in stroke. Cell Transplant 12, 449-454.

Willing, A. E., Eve, D. J. \& Sanberg, P. R. (2007). Umbilical cord blood transfusions for prevention of progressive brain injury and induction of neural recovery: an immunological perspective. Regen Med 2, 457-464.

Womble, T. A., Green, S. M., Nelson, A. P., Shahaduzzaman, M. D., Golden, J. E., Sanberg, P. R., Pennypacker, K. R. \& Willing, A. E. (2009) CD14+ and CD133+ human umbilical cord blood cells are essential for neurological recovery following MCAO. Cell Transplant 18, 240.

Wu, K. H., Cui, B., Yu, C. T. \& Liu, Y. L. (2006). Stem cells: new cell source for myocardial constructs tissue engineering. Med Hypotheses 67, 1326-1329.

Wu, K. H., Zhou, B., Mo, X. M., Cui, B., Yu, C. T., Lu, S. H., Han, Z. C. \& Liu, Y. L. (2007a). Therapeutic potential of human umbilical cord-derived stem cells in ischemic diseases. Transplant Proc 39, 1620-1622.

Wu, K. H., Zhou, B., Yu, C. T., Cui, B., Lu, S. H., Han, Z. C. \& Liu, Y. L. (2007b). Therapeutic potential of human umbilical cord derived stem cells in a rat myocardial infarction model. Ann Thorac Surg 83, 1491-1498.

Xiao, J., Nan, Z., Motooka, Y. \& Low, W. C. (2005). Transplantation of a novel cell line population of umbilical cord blood stem cells ameliorates neurological deficits associated with ischemic brain injury. Stem Cells Dev 14, 722-733. 
Xing, Y. L., Shen, L. H., Li, H. W., Zhang, Y. C., Zhao, L., Zhao, S. M. \& Xu, Q. (2009). Optimal time for human umbilical cord blood cell transplantation in rats with myocardial infarction. Chin Med J (Engl) 122, 2833-2839.

Yang, S. E., Ha, C. W., Jung, M., Jin, H. J., Lee, M., Song, H., Choi, S., Oh, W. \& Yang, Y. S. (2004). Mesenchymal stem/progenitor cells developed in cultures from UC blood. Cytotherapy 6, 476-486.

Yang, W. Z., Zhang, Y., Wu, F., Min, W. P., Minev, B., Zhang, M., Luo, X. L., Ramos, F., Ichim, T. E., Riordan, N. H. \& Hu, X. (2010). Safety evaluation of allogeneic umbilical cord blood mononuclear cell therapy for degenerative conditions. J Transl Med 8, 75 .

Yao, C. L., Feng, Y. H., Lin, X. Z., Chu, I. M., Hsieh, T. B. \& Hwang, S. M. (2006). Characterization of serum-free ex vivo-expanded hematopoietic stem cells derived from human umbilical cord blood CD133(+) cells. Stem Cells Dev 15, 70-78.

Yasuhara, T., Hara, K., Maki, M., Xu, L., Yu, G., Ali, M. M., Masuda, T., Yu, S. J., Bae, E. K., Hayashi, T., Matsukawa, N., Kaneko, Y., Kuzmin-Nichols, N., Ellovitch, S., Cruz, E. L., Klasko, S. K., Sanberg, C. D., Sanberg, P.R. \& Borlongan, C. V. (2010). Mannitol facilitates neurotrophic factor up-regulation and behavioural recovery in neonatal hypoxic-ischaemic rats with human umbilical cord blood grafts. J Cell Mol Med 14, 914-921.

Yerebakan, C., Sandica, E., Prietz, S., Klopsch, C., Ugurlucan, M., Kaminski, A., Abdija, S., Lorenzen, B., Boltze, J., Nitzsche, B., Egger, D., Barten, M., Furlani, D., Ma, N., Vollmar, B., Liebold, A. \& Steinhoff, G. (2009). Autologous umbilical cord blood mononuclear cell transplantation preserves right ventricular function in a novel model of chronic right ventricular volume overload. Cell Transplant 18, 855-868.

Yin, A. H., Miraglia, S., Zanjani, E. D., Almeida-Porada, G., Ogawa, M., Leary, A. G., Olweus, J., Kearney, J. \& Buck, D. W. (1997). AC133, a novel marker for human hematopoietic stem and progenitor cells. Blood 90, 5002-5012.

Zeisberger, S. M., Schulz, J. C., Mairhofer, M., Ponsaerts, P., Wouters, G., Doerr, D., KatsenGloba, A., Ehrbar, M., Hescheler, J., Hoerstrup, S. P., Zisch, A. H., Kolbus, A. \& Zimmermann, H. (2010). Biological and physicochemical characetrization of a serum- and xeno-free chemically defined cryopreservation procedure for adult human progenitor cells. Cell Transplant Epub ahead of print. DOI:10.3727/096368910X547426

Zigova, T., Song, S., Willing, A. E., Hudson, J. E., Newman, M. B., Saporta, S., SanchezRamos, J. \& Sanberg, P. R. (2002). Human umbilical cord blood cells express neural antigens after transplantation into the developing rat brain. Cell Transplant 11, 265274.

Zola, H., Fusco, M., Macardle, P. J., Flego, L. \& Roberton, D. (1995). Expression of cytokine receptors by human cord blood lymphocytes: comparison with adult blood lymphocytes. Pediatr Res 38, 397-403. 


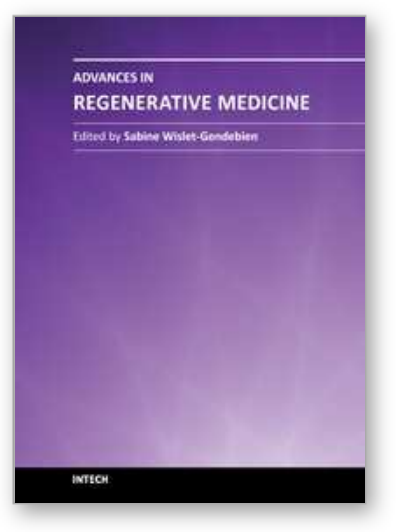

\author{
Advances in Regenerative Medicine \\ Edited by Dr Sabine Wislet-Gendebien
}

ISBN 978-953-307-732-1

Hard cover, 404 pages

Publisher InTech

Published online 21, November, 2011

Published in print edition November, 2011

Even if the origins of regenerative medicine can be found in Greek mythology, as attested by the story of Prometheus, the Greek god whose immortal liver was feasted on day after day by Zeus' eagle; many challenges persist in order to successfully regenerate lost cells, tissues or organs and rebuild all connections and functions. In this book, we will cover a few aspects of regenerative medicine highlighting major advances and remaining challenges in cellular therapy and tissue/organ engineering.

\title{
How to reference
}

In order to correctly reference this scholarly work, feel free to copy and paste the following:

Dong-Hyuk Park, Jeong-Hyun Lee, David J. Eve, Cesario V. Borlongan, Paul R. Sanberg, Yong-Gu Chung and Tai-Hyoung Cho (2011). Human Umbilical Cord Blood Stem Cells Rescue Ischemic Tissues, Advances in Regenerative Medicine, Dr Sabine Wislet-Gendebien (Ed.), ISBN: 978-953-307-732-1, InTech, Available from: http://www.intechopen.com/books/advances-in-regenerative-medicine/human-umbilical-cord-blood-stem-cellsrescue-ischemic-tissues

\section{INTECH}

open science | open minds

\section{InTech Europe}

University Campus STeP Ri

Slavka Krautzeka 83/A

51000 Rijeka, Croatia

Phone: +385 (51) 770447

Fax: +385 (51) 686166

www.intechopen.com

\section{InTech China}

Unit 405, Office Block, Hotel Equatorial Shanghai

No.65, Yan An Road (West), Shanghai, 200040, China

中国上海市延安西路65号上海国际贵都大饭店办公楼 405 单元

Phone: +86-21-62489820

Fax: +86-21-62489821 
(C) 2011 The Author(s). Licensee IntechOpen. This is an open access article distributed under the terms of the Creative Commons Attribution 3.0 License, which permits unrestricted use, distribution, and reproduction in any medium, provided the original work is properly cited. 